\title{
A comparative study on color and dimensional stability of esthetic indirect dental materials
}

\author{
Hye-Yun Heo ${ }^{1}$, Hyo-Jin Son ${ }^{2}$, Yu-Ri Heo ${ }^{1}$, and Mee-Kyoung Son ${ }^{1,2 \star}$ \\ ${ }^{1}$ Department of Prosthodontics, School of Dentistry, Chosun University, Gwangju, Republic of Korea \\ ${ }^{2}$ Oral Biology Research Institute, Chosun University, Gwangju, Republic of Korea
}

In selecting dental materials, color and dimensional stability play key roles in mechanical characteristics as well as esthetic aspects. While resin nano ceramics have been examined to determine their mechanical characteristics in carious experiments, few studies have focused on their intra-oral stability, specifically their long-term color stability or water sorption. In this study, ceramic, resin nano ceramic, and composite resin were analyzed to evaluate their color stability, water sorption, and solubility. The amount of characteristic changes was measured using a spectrometer, an electronic scale, and a caliper for durations of 1,2, 4, and 8 weeks. The results showed that ceramic was the most stable among all materials, whereas resin nano ceramic and composite resin demonstrated time-dependent changes, which require more clinical considerations for long-term use.

Key Words: Color stability, Esthetic indirect dental materials, Water absorption, Water solubility

(c) This is an open-access article distributed under the terms of the Creative Commons Attribution Non-Commercial License (http://creativecommons.org/licenses/by-nc/4.0) which permits unrestricted noncommercial use, distribution, and reproduction in any medium, provided the original work is properly cited.

\section{서 론}

치과 보철치료에 있어 수복치료부터 광범위한 결손치료에 이 르기까지 치과 재료의 심미성은 중요한 요소로 고려된다. 과거 에는 전치부에 국한되어 있던 심미성에 대한 요구가 구치부까 지 확대되는 추세로, 치아 우식이나 치아 파절로 인한 인레이 수 복, 전장관, 계속 가공의치, 임플란트 치료 등을 포함한 광범위 한 보철 분야에서 심미적 조화에 대한 고려가 필요해졌다[1].

심미성을 위해서 치아색을 재현하기 위해 많은 노력들이 이 루어졌다. 심미치료를 위해 세라믹과 복합레진이 개발되었으나 세라믹의 경우 복잡한 제작 과정과 파절 위험성, 대합치 마모라 는 단점이 있고, 복합레진의 경우 성형성이 좋고 심미성과 내구 성은 만족시키나 중합 시 수축, 치질보다 큰 열팽창계수, 강도
와 내마모성 부족, 변색의 취약성, 색의 깊이 부족, 사용 중 광택 의 소실과 같은 문제가 있다[2,3]. 이러한 단점을 보완하기 위해 미국에서 간접수복용 세라믹 고분자 제품인 Paradigm MZ100 (3M ESPE, St. Paul, MN, USA)이 최초로 개발되었다[4].

또 다른 제품으로는 Lava Ultimate (3M ESPE, Bad Seefeld, Germany)가 resin based nanocomposite로 소개되었는데[5], 이는 세라믹이나 복합레진이라기 보다는 두 성분의 혼합으로 제조사는 이를 resin nano ceramic (RNC)으로 분류하였으며 고분자 매트릭스에 불규칙한 세라믹 필러가 분산된 구조를 갖 는 제품으로 수십 $\mu \mathrm{m}$ 와 수십 $\mathrm{nm}$ 가 섞여 있는 하이브리드 필러 로 구성된다[6,7]. 전통적인 세라믹과 복합레진의 장점을 혼합 하여 우수한 심미성과 가공성을 향상시키는 것을 목표로 세라 믹과 폴리머의 이중 구조로 물성을 개선하여 시판중인 $\mathrm{RNC}$ 들

Received October 21, 2019; Revised November 21, 2019; Accepted November 23, 2019

*Corresponding author: Mee-Kyoung Son, Department of Prosthodontics, School of Dentistry, Chosun University, 309 Pilmun-daero, Donggu, Gwangju 61452, Republic of Korea.

Tel: +82-62-220-3820, Fax: +82-62-227-7811, E-mail: son0513@chosun.ac.kr

Copyright @ 2019, Oral Biology Research Institute 
은 향상된 심미성과 강도, 내구성을 보이며[8], 국내 제품으로는 Polyglass (Vericom, Anyang, Korea)가 있다.

Yi와 Cho [9]에 의하면 색안정성은 심미상 매우 중요하며 색 소 침착, 시간에 따른 색 변화, 색 부조화는 보철물 재제작의 원 인이 된다. 색안정성은 여러 환경에서 오랜 기간 동안 재료 자체 의 색상을 유지하는 성질을 말하며 이는 중요한 물리적 성질 중 하나이다. 이런 색안정성에 영향을 주는 요소로 색소 부착 또는 흡수, 수분, 표면 활택도, 재료성분, 중합상태, 재료의 마모 등이 있어 RNC나 복합레진이 세라믹보다 색안정성이 떨어지는 이유 가 된다[10,11].

치과 재료는 심미성 이외에도 체적안정성, 적절한 변연 적합 도나 수명, 내마모도와 같이 구강 내 안정을 위한 요구 조건이 있다. 구강 내 보철물은 구강 환경으로 인해 타액, 온도와 산도 $(\mathrm{pH})$ 변화 등에 노출되어 있어 이런 습한 조건에서도 적절한 물 성 유지가 중요하다[9,12].

타액 속 수분은 충전재와 기질 사이 또는 기질 자체에 영향을 미쳐 기계적 물성 약화[13-16], 마모저항 감소, 체적안정성과 색안정성 저하를 일으킨다. 특히 복합레진의 경우, 체적 변화는 중합에 의한 수축과 수분 흡수에 따른 팽창이 있으며 수분 흡수 는 주로 레진에 의해 직접 발생하여 수분 흡수 정도는 복합레진 함량과 레진-충전재 결합 강도에 의한다. RNC의 구강 내 사용 을 위한 다양한 기계적 물성 실험이 선행되었으며 실제 임상에 서의 비교 평가도 이루어지고 있지만 이런 기계적 물성 외에도 장기간 사용 시 색안정성, 흡수율 등 구강 내 안정성에 대한 논 문은 제한적이다.

이에 본 연구에서는 현재 시판되는 세라믹과 $\mathrm{RNC}$, 복합레진 을 이용하여 일정 기간 침전시킨 후 분광광도계를 이용하여 얻 어진 색상 변화를 측정하여 비교 분석하고 구강 내 습한 환경에 서 수분 흡수와 용해가 나타나는지 시간에 따른 차이를 비교해 보고자 한다. 본 연구는 치과임상에서 사용하고 있는 심미 재료 인 세라믹, $\mathrm{RNC}$, 복합레진의 색안정성과 체적안정성을 구강 환 경에서 유사한 환경에서 평가하고자 한다.

\section{대상 및 방법}

\section{연구 재료}

본 연구에서는 3종의 간접 수복 재료로 세라믹(Vintage Halo; Shofu, Kyoto, Japan), RNC (Polyglass; Vericom), 복합레진 (Gradia indirect; GC, Tokyo, Japan)을 사용하였다.

\section{연구 방법}

\section{시편제작(specimens fabrication)}

3종의 각기 다른 재료를 이용한 실험 시편은 A2 shade 직경 $10 \mathrm{~mm}$, 두께 $2 \mathrm{~mm}$ 의 디스크 형태로 제조사의 지시에 따라 제 작되었으며[17], 실험을 위해 종류별로 40개씩 총 120 개의 시 편이 준비되었다. 제작된 시편의 연마는 각 재료의 추천되는 방 법을 사용하였다(Fig. 1).

\section{세라믹}

Mylar strip 없이 금속 주형을 이용하여 세라믹을 한 번 소성 한 후 제조사의 지시에 따라 연마하였다(Fig. 1A). 표면 처리를 위해 시편 제작 후, 각 시편의 수평과 표면 조건을 동일화하기 위해 한 쪽 표면을 green stone bur로 고르게 연마하고, 사포를 이용하여 grit 200, 400, 600 순으로 활택한 후, 흐르는 물에 30 초 동안 세척하고 압축공기로 건조하였다.

\section{RNC 및 복합레진}

원형 분할 금속판에 RNC 및 복합레진을 채운 후 Mylar strip 을 덮고 압력을 가해(axial load of $500 \mathrm{~g}$ for 30 seconds) 잉여 분을 제거한다. 그 후 2장의 슬라이드 글라스로 덮어 중합 방해 층 발생을 억제하고 원형 분할 금속판으로 분할한다. 제조사의 지시에 따라 중합 후 금속 주형에서 분리하였다(Fig. 1B). 세라 믹, $\mathrm{RNC}$, 복합레진 군들의 시편들은 제조사의 지시에 따라 연 마하였다.

\section{색안정성 실험(color stability test)}

제작된 시편 중 종류별로 각각 20 개씩 총 60 개의 시편이 색안 정성 실험을 위해 사용되었다[17]. 각 시편은 측정이 필요하지
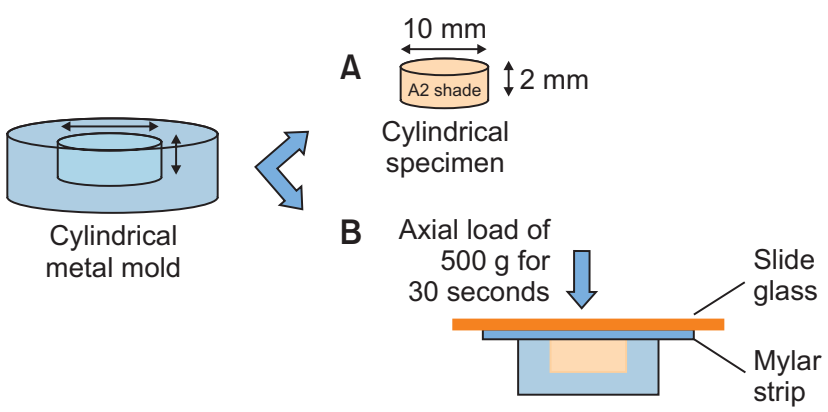

Fig. 1. A Schematic representaion of the specimen fabrication. (A) A cylindrical specimen. (B) Schematic view of the RNC and resin manufacturing. 
않은 한 쪽 면에 1 부터 20 까지 숫자를 기록하여 구분하였다. 이 들 시편은 10 개씩 2 개의 그룹으로 나누어 커피, 증류수 두 가지 음료에 침전시켰다.

커피 용액은 $250 \mathrm{~mL}$ 의 끓인 증류수에 $15 \mathrm{~g}$ 의 커피(Maxim Original; Dongsuh, Seoul, Korea)를 넣고 10분간 저은 후 여 과지에 통과시켜 제조하였고, 증류수도 $250 \mathrm{~mL}$ 준비하여 두 가 지 음료는 각각 5 개의 $200 \mathrm{~mL}$ 용기에 $50 \mathrm{~mL}$ 씩 넣고 각 재료별 로 2개씩 시편을 침전시켰으며, 용기 내에서 시편 간 접촉이 발 생하지 않도록 최대한 주의하여 침전시켰다. 시편이 침전된 용 기는 실온 암실에서 8주 동안 보관하였다.

시편의 색은 분광광도계(SpectroShade Micro; MHT, Switzerland)를 이용하여 측정하였다. 먼저 각 시편을 음료에 침전 하기 전에 색상을 측정, 기록하였고, 시편을 각각의 음료에 침전 시켜 1 주, 2 주, 4 주, 8 주 경과 시에 꺼내 증류수에 세척한 다음 티슈페이퍼로 표면을 닦고 분광광도계를 이용해 색을 측정하였 다. 색조 측정을 위해 분광광도계의 광학부에 흡광통을 놓고 영 점 조정 후 표준 백색판을 사용해 표준 조정 후 시편을 광학부 에 밀착시켰다. 측정 부위에 따른 오차를 줄이기 위하여 각 시편 은 다른 3부위를 무작위 선택하여 한 부위를 3회 측정 후 그 평 균값으로 CIE L*a*b system을 이용해 기록되었다. 침전 전과 각 측정시기의 색 변화는 색차 $(\Delta \mathrm{E})$ 로 기록되었으며, 계산하는 방 법은 다음과 같다.

\author{
$\Delta \mathrm{E}=\left\{(\Delta \mathrm{L})^{2}+(\Delta \mathrm{a})^{2}+(\Delta \mathrm{b})^{2}\right\}^{1 / 2}$ \\ $\mathrm{L}$ : white와 black의 정도, $\Delta \mathrm{L}=\mathrm{L}_{\mathrm{t}}-\mathrm{L}_{0}$ \\ $\mathrm{a}$ : redness와 greeness의 정도, $\Delta \mathrm{a}=\mathrm{a}_{\mathrm{t}}-\mathrm{a}_{0}$ \\ $\mathrm{b}$ : yellowness와 blueness의 정도, $\Delta \mathrm{b}=\mathrm{b}_{\mathrm{t}}-\mathrm{b}_{0}$ \\ (Lt, at, bt: 침전 후 측정 시기에서의 수치 $/ \mathrm{L}_{0}, \mathrm{a}_{0}, \mathrm{~b}_{0}$ : 침전 전 수치)
}

\section{수분 흡수율과 용해도 실험}

제작된 시편 중 종류별로 각각 20 개씩 총 60 개의 시편이 수분 흡수 및 용해 실험에 사용되었다. 실험 전 각 시편의 직경과 두 께가 전자 caliper를 이용하여 측정되었으며, 이를 바탕으로 시 편의 부피(V)가 계산되었다. 시편의 부피 변화를 측정하기 위해 $\operatorname{disc}$ 원주의 4 등분점과 중앙 한 점을 표시하였으며 $37^{\circ} \mathrm{C}$ 탈이온 수에 24시간 동안 저장 후 disc의 baseline 두께와 직경을 계측 하였다.

수분 흡수와 용해에 의한 체적 변화와 무게의 변화를 관찰하 기 위해 시편들은 1 주, 2 주, 4 주, 8 주간 증류수에 보관되었고 외 부로부터의 오염을 방지하기 위해 밀봉하였으며 측정 시에만 공기 중에 노출하였다. 시편들은 질량이 유지되는 국제표준화 기구(International Organization for Standardization) 기준에
의거해 중합 직후 몰드를 제거하여 초기질량을 측정하였고 초 기 질량 $\left(\mathrm{m}_{1}\right)$ 측정 후 시편들은 증류수로 옮겨져 1 주, 2 주, 4 주, 8 주간 $37^{\circ} \mathrm{C}$ 항온수조에 보관하였다. 시편들은 침전 시작 후 1 주, 2 주, 4 주, 8 주에 각각 질량을 측정했다. 저장 후 시편들은 용액 에서 제거되어 paper 건조시켜 침전 후의 질량 $\left(\mathrm{m}_{2}\right)$ 을 측정하였 으며 이후 $37^{\circ} \mathrm{C}$ 건조오븐에서 24 시간 동안 건조시킨 질량 $\left(\mathrm{m}_{3}\right)$ 을 측정하였다.

무게의 변화는 시편의 표면과 내면의 수분을 거즈와 paper towel을 이용하여 제거한 후 전자식 저울(Libror AEX-200G; Shimadzu Corp., Koto, Japan)을 사용하여 측정하였다. 중량 의 측정은 표시되는 측정값이 안정된 후 10 초간 나타난 값을 기 록하였다. 측정된 시편은 다시 사용하지 않았으며 정해진 시간 간격에 따라 측정하였다. 흡수(water absorption, Wsp)와 용해 (water solubility, Wsl)를 다음 방정식에 의해 계산하였다.

$$
\mathrm{Wsp}=\left(\mathrm{m}_{2}-\mathrm{m}_{3}\right) / \mathrm{V}, \mathrm{Wsl}=\left(\mathrm{m}_{1}-\mathrm{m}_{3}\right) / \mathrm{V}[18]
$$

\section{통계분석}

통계적 분석은 IBM SPSS ver. 22.0 (IBM Corp., Armonk, $\mathrm{NY}, \mathrm{USA}$ )을 이용하였다. 커피 침전 시 색 변화와 증류수에서의 재료별 흡수율 평가 시 Shapiro-Wilk test 결과에 의해 정규성 을 만족하는 것을 확인하였고, Levene's test에 의한 등분산 가 정을 만족하여 모수방법인 일원배치 분산분석(one-way analysis of variance)으로 통계분석을 시행하였으며, Tukey test와 Bonferroni's method로 사후 검정하였다. 모든 결과는 $p<0.05$ 수준에서 유의성 검정을 실시하였다. 증류수 침전 시 색 변화와 재료의 용해도 값은 Shapiro-Wilk test 결과에서 정규성을 만족 하지 못하였기 때문에 비모수 방법인 Kruskal-Wallis test로 통 계 분석하였다. 두 군씩 쌍을 지어 각각 Mann-Whitney U-test 를 시행 후, Bonferroni's method로 제 1종 오류를 보정하여 $p<0.05$ 수준에서 유의성을 검정하였다.

\section{결 과}

\section{색안정성}

세 가지 종류의 시편을 증류수와 커피에 침전 후 1 주, 2 주, 4 주, 8 주 경과 시 측정하여 색조 변화의 평균 $\Delta \mathrm{E}$ 값을 평가하였 다. 각 재료별로 증류수와 커피에서 평균 $\Delta \mathrm{E}$ 값을 비교하였을 때 모든 재료가 커피에서 증류수 보다 평균 $\Delta \mathrm{E}$ 값이 증가하였으 나 모든 재료에서 전 기간 동안 증류수에서의 색조 변화는 유의 한 차이가 없었다( $p>0.05$; Fig. 2, 3). RNC를 커피에 침전했을 


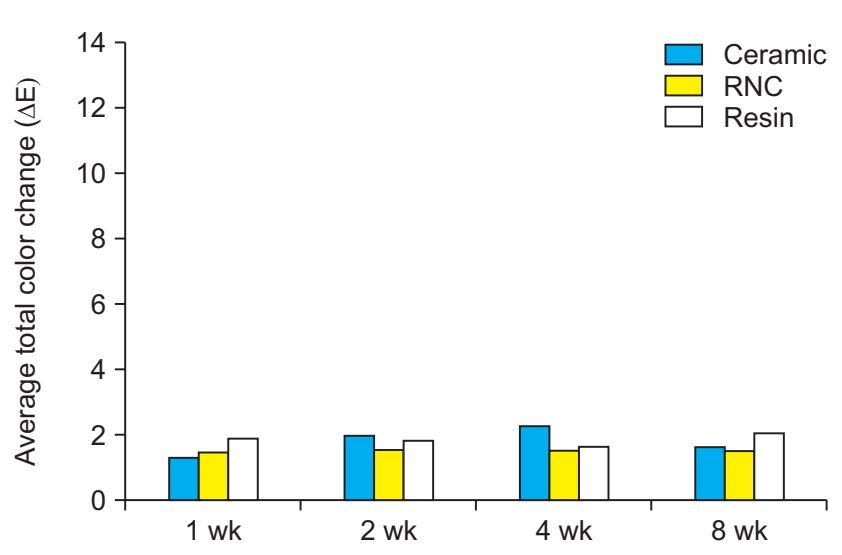

Fig. 2. Average total color change $(\Delta \mathrm{E})$ in distilled water. Ceramic, RNC, Resin.

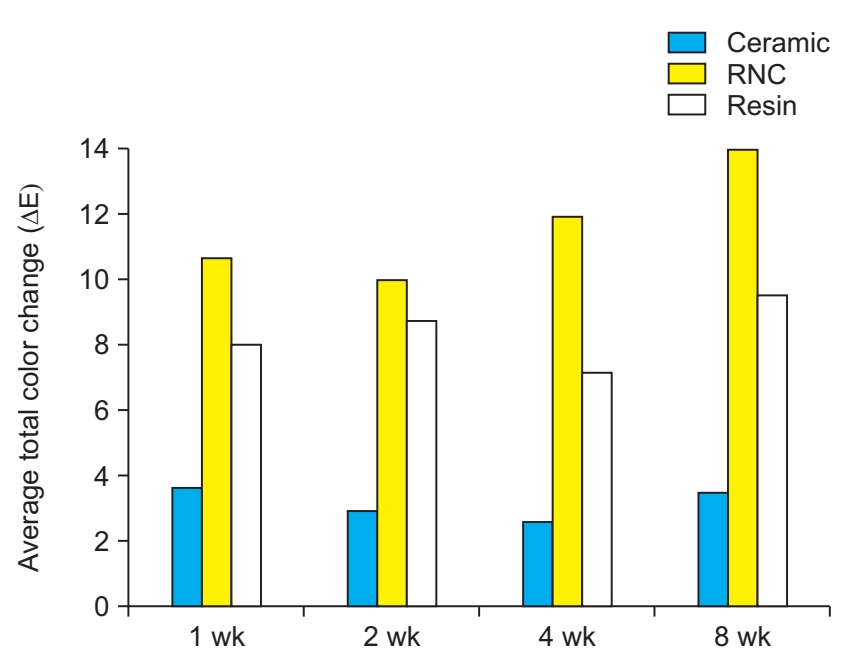

Fig. 3. Average total color change $(\Delta \mathrm{E})$ in coffee solution. Ceramic, RNC, Resin.

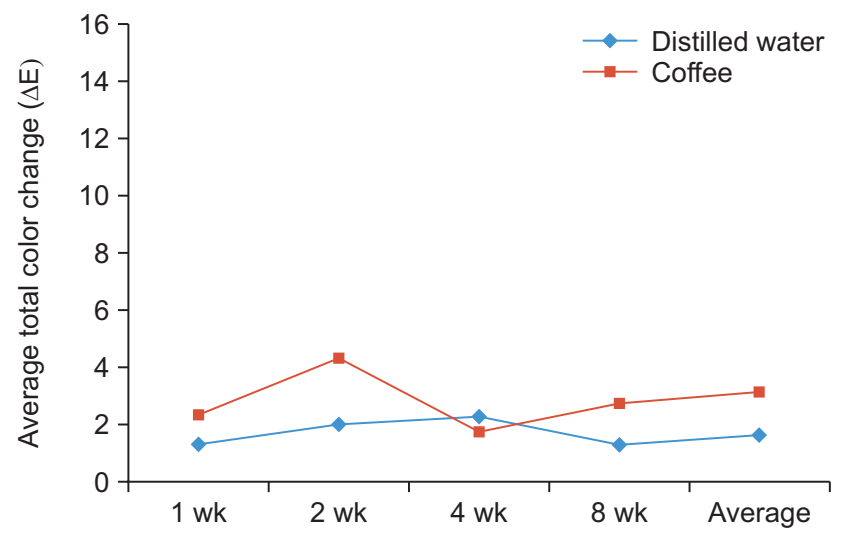

Fig. 4. Average total color change $(\Delta \mathrm{E})$ of ceramic in distilled water and coffee solution.

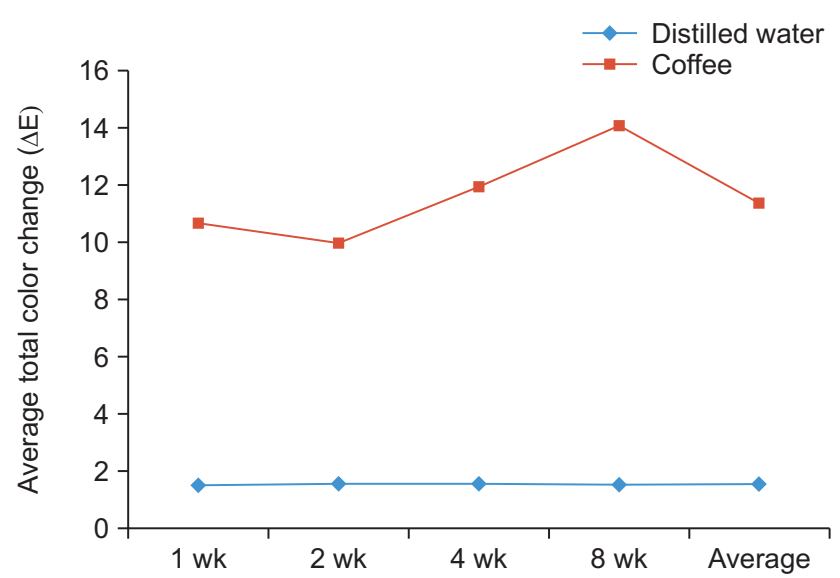

Fig. 5. Average total color change $(\Delta \mathrm{E})$ of resin nano ceramic in distilled water and coffee solution.

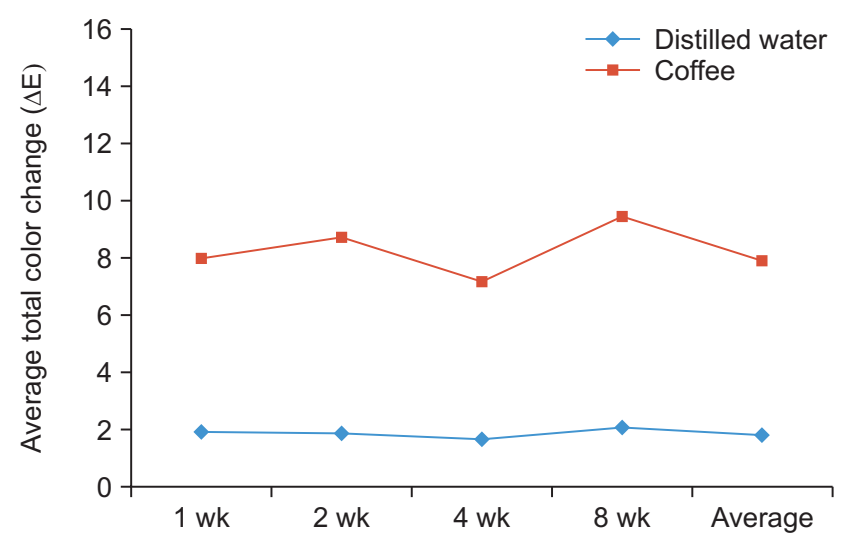

Fig. 6. Average total color change $(\Delta \mathrm{E})$ of composite resin in distilled water and coffee solution.

때 평균 $\Delta \mathrm{E}$ 값이 가장 증가하였으며 커피용액에서 세 가지 재료 의 평균 $\Delta \mathrm{E}$ 값은 유의한 차이 $(p<0.05)$ 가 관찰되었다(Fig. 3).

모든 평가 시기에서 세라믹은 증류수와 커피 용액 모두 주수 별 $\Delta \mathrm{E}$ 의 유의한 차이가 나타나지 않았지만 증류수보다 커피용 액에서 색 변화가 크게 관찰되었고(Fig. 4) 이는 통계적으로 유 의한 차이를 보였다 $(p<0.05)$. 증류수와 커피용액에서 각 재료 별 평균 색 변화 비교 시 모든 재료가 증류수에 침전했을 때보다 커피에 침전했을 때(Fig. 3) 유의한 $\Delta \mathrm{E}$ 의 증가가 관찰되었지만 $(p<0.05)$, 세라믹의 평균 색 변화 수치가 가장 낮았다(Fig. 4). $\mathrm{RNC}$ 는 커피에 침전시켰을 때 시간에 따른 $\Delta \mathrm{E}$ 의 유의한 증가 가 관찰되었으며 $(p<0.05)$ 특히 8 주차 변화량이 가장 높게 측정 되었다(Fig. 5). 복합레진은 커피용액에서 시간에 따라 $\Delta \mathrm{E}$ 값이 증가하여 8주차 변화량에서 가장 높게 관찰되었으나(Fig. 6) 통 계적으로 커피에서와 증류수에서 모두 $\Delta \mathrm{E}$ 변화량의 유의한 차 이는 없었다 $(p>0.05)$. 


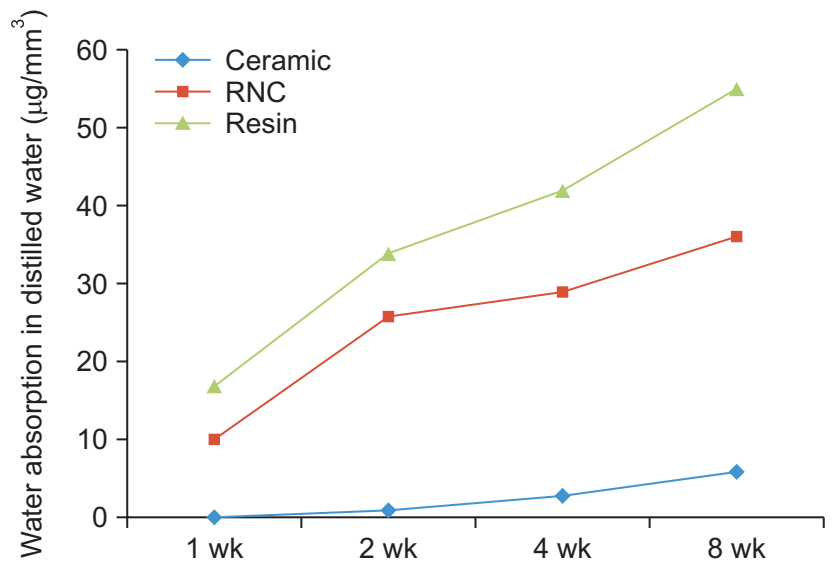

Fig. 7. Water absorption in distilled water. Ceramic, RNC, Resin.

\section{수분 흡수율과 용해도}

본 연구에서는 8주 동안 증류수에 침전시켰을 때 나타나는 3 가지 재료에 따른 수분 흡수와 용해도의 평균 변화를 평가하였 다. 재료에 따른 수분 흡수와 용해도의 변화를 관찰 시 세라믹의 흡수율과 용해도가 가장 적었고 복합레진에서 가장 많았다. 특 히 RNC와 복합레진에서 시간에 따른 흡수율과 용해도 변화가 두드러졌으며 시간이 증가할수록 흡수율과 용해도도 유의하게 증가하였다 $(p<0.05)$. 수분 흡수율은 복합레진, RNC, 세라믹 순으로 높았으며(Fig. 7), 세라믹과 복합레진 간에는 통계적으로 유의한 차이가 관찰되었다 $(p<0.05)$. 또한 재료간 용해도에서 는 유의한 차이가 관찰되었으며 $(p<0.05)$, 복합레진에서 용해 도가 가장 높았고 세라믹이 가장 낮았다(Fig. 8).

\section{고 찰}

본 실험에서 세 가지 종류의 시편을 증류수와 커피에 1 주, 2 주, 4 주, 8 주간 침전시켰을 때 색 변화의 평균 $\Delta \mathrm{E}$ 값은 시간에 따라 점차 증가하였다. 이는 Lee [12]에 의하면 전체 실험군의 $\Delta \mathrm{E}$ 값의 비교 시 모든 군이 침전 시간에 따라 $\Delta \mathrm{E}$ 값이 증가하 였다는 보고와 일치한다.

세라믹, RNC, 복합레진을 비교 하였을 때 세라믹의 $\Delta \mathrm{E}$ 가 가 장 작았고 $\mathrm{RNC}$ 와 복합레진의 $\triangle \mathrm{E}$ 는 크게 증가하는 것을 관찰 할 수 있었다. Jain 등[19]은 복합레진의 $\Delta \mathrm{E}$ 변화를 3 주간 관찰 하였고 시간에 따라 $\Delta \mathrm{E}$ 가 증가하였으며 3 주차에는 최대 8.4 의 $\Delta \mathrm{E}$ 변화량이 관찰되어 위 실험의 변화량 수치와 유사하게 측정 되었다.

착색의 정도 차이는 연구에 사용된 복합레진의 종류, 시편 표 면 거칠기, 다공성의 정도, 복합레진 중합 방법, 실험 재료로 쓰

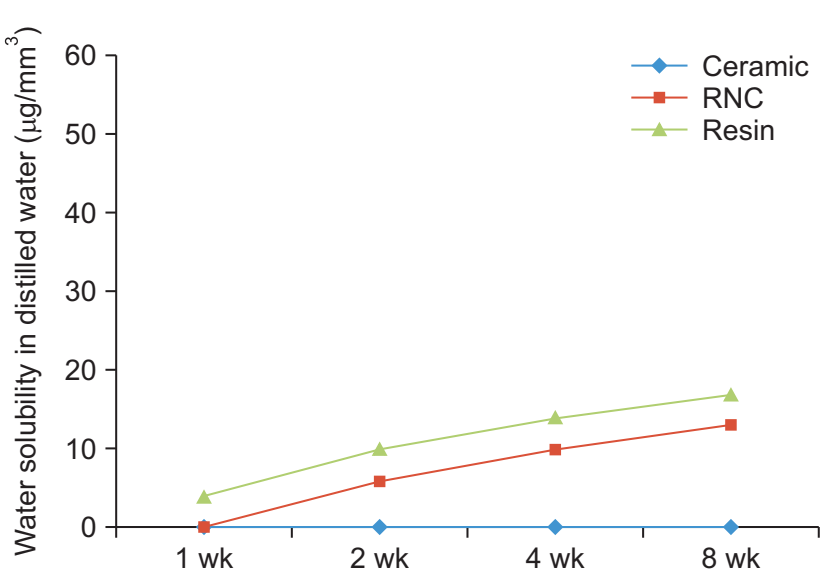

Fig. 8. Water solubility in distilled water. Ceramic, RNC, Resin.

인 용액의 성분이나 제조법 등의 다양성으로 인한 것으로 판단 된다. 다른 논문들과 달리 이번 실험에서 $\Delta \mathrm{E}$ 값의 증가가 더욱 두드러진 것은 시편의 커피 용액 침전시간이 8 주로 매우 길었기 때문으로 생각된다. 이는 시간에 따라 $\Delta \mathrm{E}$ 값의 변화가 유의하 게 증가하며 기간이 길어질수록 $\Delta \mathrm{E}$ 값이 커졌다고 보고한 Jain 등[20]의 연구 결과와 같다.

Guler 등[21]에 의하면 커피와 차에 함유된 수용성 물질인 탄 닌산(tannic acid)은 갈색 착색을 유발한다고 알려져 있다. 착 색은 커피에 포함된 다른 극성을 갖는 황색 색소로 인하며[22] 커피에 의한 착색은 색소의 흡착과 색소와 재료의 호환에 따른 흡수에 의한 복합적 작용이므로 더 많은 영향을 준다고 하였다 [23].

Jeong 등[24]과 Belli 등[25]에 의하면 RNC는 zirconia-silica nanofillers (80\%)와 resin matrix (20\%)가 입자형태로 퍼지거 나 뭉쳐진 형태로 레진 매트릭스의 중합이 필요하므로 궁극적 으로는 복합레진의 분류 안에 포함된다고 할 수 있다. RNC는 성분 중 충전재 함량을 변화시켰음에도 불구하고 레진 기질 구 조가 남아 있어 구강 내 변화가 보고된다. 광택 소실, 변색과 같 은 임상적 증상은 기계적, 화학적, 온도, 빛과 같은 자극에 의해 유발된 RNC 성질의 변화로 여겨진다[26].

본 실험에서는 세라믹, RNC, 복합레진을 비교하여 수분 흡수 와 용해를 평가하였는데 레진 기질이 가장 많은 간접 수복용 복 합레진에서 가장 큰 수분 흡수와 용해 정도를 관찰할 수 있었다. 또한 시간에 따라 수분 흡수와 용해 정도가 증가하는 것이 관찰 되었는데 이는 Noort [27]의 연구에서도 시편의 침적시간에 따 라 수분 흡수로 인한 팽창이 증가하였다고 보고되었다. 모든 시 점에서 수분 흡수가 용해보다 많은 것으로 관찰되었는데 Kim 등[28]의 연구 결과에서도 수분 흡수 정도가 용해 정도보다 많 게 보고되었다. 
세라믹의 경우 일단 소성되면 표면 거칠기에 의한 외부 착색 외에는 변색이 거의 없으나 RNC는 무기질 필러 함량을 높여 물 성을 증가시켰지만 남아 있는 레진 기질로 인해 같은 경향[8,29] 을 보이며 복합레진은 기질과의 결합이 구강 내 환경에서 파괴 되면서 착색, 수분 흡수와 용해 과정 등 많은 변화가 관찰된다.

치과 수복재는 습한 환경에서 적절한 안정성을 유지하는 것 이 필요하므로 수분 흡수와 용해 관점에서 복합레진의 수분 흡 수로 인한 체적 변화에 관하여 다양한 연구들이 존재한다[3033]. 이들 논문에서 수분 흡수와 복합레진의 체적 변화는 비례 하며 수분 흡수와 용해 정도는 제품의 성분과 중합 방식과 관계 가 있다고 알려져 있다. Yi와 Cho [9]에 따르면 구강은 항상 타 액에 노출되며 각종 색소, 음식물의 산도, 온도에 영향을 받아 충전재와 기질 사이, 기질 자체에 영향을 미쳐 계면분리나 충전 재를 녹이는 작용하므로 복합레진의 색안정성을 떨어뜨리는 환 경이라고 알려져 있다. Noort [27]와 Hirasawa 등[31]은 레진 기질 함유량에 따라 복합레진의 수분 흡수 팽창은 직접적으로 관계가 있다고 보고하였다.

강력한 착색 작용이 있는 커피를 포함한 착색성 음식물이 구 강 내로 불규칙하게 투여되어 지속적으로 접촉하지 않으므로 추가적인 이해가 필요하나 본 연구에 사용된 RNC와 복합레진 은 세라믹보다 색안정성이 떨어지므로 색안정성을 개선하기 위 한 추가적 연구가 필요하다. 더불어 RNC나 복합레진의 수분 흡 수와 팽창 또한 기질 함유량에 따라 변화하므로 수분 흡수에 의 한 계면분리나 충전재 용해를 줄이기 위해서는 우선 재료 자체 의 기질 성분에 강한 교차결합을 부여하는 것이 필요하며 수복 재료별 기질 함량이 매우 다양 하므로 개발된 여러 재료들에 대 한 다양한 연구가 요구된다.

\section{ACKNOWLEDGEMENTS}

This study was supported by a research fund from Chosun University, 2018.

\section{CONFLICTS OF INTEREST}

The authors declare that they have no competing interests.

\section{ORCID}

\author{
Hye-Yun Heo \\ https://orcid.org/0000-0003-2378-1367
}

Hyo-Jin Son

https://orcid.org/0000-0002-9553-5336

Yu-Ri Heo

https://orcid.org/0000-0002-1806-3822

Mee-Kyoung Son

https://orcid.org/0000-0001-9225-1744

\section{REFERENCES}

1. Park SH, Lee SY, Cho YS, Kim SS, Lee CJ, Kim YJ, Lee BH, Lee KS, Noh BD. Amount of polymerization shrinkage and shrinkage stress in composites and compomers for posterior restoration. J Korean Acad Conserv Dent 2003;28:348353. doi: 10.5395/JKACD.2003.28.4.348.

2. Ryu SY, Lim JH, Cho IH. A study on the color stability of porcelain for porcelain fused to metal crown. J Korean Acad Prosthodont 2000;38:73-84.

3. Seghi RR. Effects of instrument-measuring geometry on colorimetric assessments of dental porcelains. J Dent Res 1990;69:1180-1183. doi: 10.1177/00220345900690051101.

4. Lee CY, Son SK, Ko YM. Effect of surface roughness on the mechanical properties of ceramic-polymer blocks for CAD/ CAM dental restoration. Korean J Dent Mater 2018;45:111128. doi: $10.14815 / \mathrm{kjdm} .2018 .45 .2 .111$.

5. Mörmann WH, Stawarczyk B, Ender A, Sener B, Attin T, Mehl A. Wear characteristics of current aesthetic dental restorative CAD/CAM materials: two-body wear, gloss retention, roughness and Martens hardness. J Mech Behav Biomed Mater 2013;20:113-125. doi: 10.1016/ j.jmbbm.2013.01.003.

6. Koller M, Arnetzl GV, Holly L, Arnetzl G. Lava ultimate resin nano ceramic for CAD/ CAM: customization case study. Int J Comput Dent 2012;15:159-164. German.

7. Spitznagel FA, Horvath SD, Guess PC, Blatz MB. Resin bond to indirect composite and new ceramic/polymer materials: a review of the literature. J Esthet Restor Dent 2014;26:382-393. doi: 10.1111/jerd.12100.

8. Terry DA. Direct applications of a nanocomposite resin system: part 1--The evolution of contemporary composite materials. Pract Proced Aesthet Dent 2004;16:417-422.

9. Yi YJ, Cho LR. Color stability of ceromers after thermocycling and brushing. J Korean Acad Prosthodont 2001;39:37-48.

10. Um CM, Ruyter IE. Staining of resin-based veneering materials with coffee and tea. Quintessence Int 1991;22:377386.

11. Dietschi D, Campanile G, Holz J, Meyer JM. Comparison of the color stability of ten new-generation composites: an in vitro study. Dent Mater 1994;10:353-362. doi: 10.1016/0109-5641(94)90059-0.

12. Lee JH. Dimensional changes of ceromer crown by water 
absorption. J Korean Acad Prosthodont 2009;47:119-124. doi: 10.4047/jkap.2009.47.2.119.

13. Draughn RA, Bowen RL, Moffa JP. Composites restorative materials. In: Reese JA, Valega TM, editors. Restorative dental materials: an overview. London: Fédération Dentaire Internationale; 1985. p. 75-107.

14. Oysaed H, Ruyter IE. Composites for use in posterior teeth: mechanical properties tested under dry and wet conditions. J Biomed Mater Res 1986;20:261-271. doi: 10.1002/ jbm.820200214.

15. Calais JG, Söderholm KJ. Influence of filler type and water exposure on flexural strength of experimental composite resins. J Dent Res 1988;67:836-840. doi: 10.1177/00220345880670050801.

16. Mohsen NM, Craig RG. Hydrolytic stability of silanated zirconia-silica-urethane dimethacrylate composites. J Oral Rehabil 1995;22:213-220. doi: 10.1111/j.1365-2842.1995. tb01566.x.

17. Nikzad S, Azari A, Poursina M. Effects of beverage colorants and accelerated aging on the color stability of indirect resin composites. J Dental Sci 2012;7:231-237. doi: 10.1016/ j.jds.2012.05.006.

18. Park JH, Park JH, Ko YM. Fabrication of composite resin block using lithium disilicate glass-ceramics for dental CAD/CAM restoration. Kor J Dent Mater 2016;43:247-255.

19. Jain V, Platt JA, Moore K, Spohr AM, Borges GA. Color stability, gloss, and surface roughness of indirect composite resins. J Oral Sci 2013;55:9-15. doi: 10.2334/josnusd.55.9.

20. Jain C, Bhargava A, Gupta S, Rath R, Nagpal A, Kumar P. Spectrophotometric evaluation of the color changes of different feldspathic porcelains after exposure to commonly consumed beverages. Eur J Dent 2013;7:172-180. doi: 10.4103/1305-7456.110165.

21. Guler AU, Yilmaz F, Kulunk T, Guler E, Kurt S. Effects of different drinks on stainability of resin composite provisional restorative materials. J Prosthet Dent 2005;94:118124. doi: 10.1016/j.prosdent.2005.05.004.

22. Sepúlveda-Navarro WF, Arana-Correa BE, Borges CP, Jorge JH, Urban VM, Campanha NH. Color stability of resins and nylon as denture base material in beverages. J Prosthodont 2011;20:632-638. doi: 10.1111/j.1532-849X.2011.00791. $\mathrm{x}$.

23. Jang DE, Lee JY, Jang HS, Lee JJ, Son MK. Color stability, water sorption and cytotoxicity of thermoplastic acrylic resin for non metal clasp denture. J Adv Prosthodont 2015:7:278-287. doi: 10.4047/jap.2015.7.4.278.

24. Jeong CS, Bae JM, Kim JM, Park YB, Oh S. The evaluation of the shear bond strength between various Hybrid CAD/ CAM restorative materials and repairing composite resins. Korean J Dent Mater 2018;45:45-56. doi: 10.14815/ kjdm.2018.45.1.45.

25. Belli R, Geinzer E, Muschweck A, Petschelt A, Lohbauer U. Mechanical fatigue degradation of ceramics versus resin composites for dental restorations. Dent Mater 2014;30:424-432. doi: 10.1016/j.dental.2014.01.003.

26. Flury S, Diebold E, Peutzfeldt A, Lussi A. Effect of artificial toothbrushing and water storage on the surface roughness and micromechanical properties of tooth-colored CADCAM materials. J Prosthet Dent 2017;117:767-774. doi: 10.1016/j.prosdent.2016.08.034.

27. Noort RV. Resin composites and polyacid modified resin composites. In: Noort RV, editor. Introduction to dental materials. 2nd ed. Edinburgh: Mosby; 2002. p. 96-123.

28. Kim SJ, Shin SW, Han JS, Suh KW. Marginal fitness and marginal leakage of fiber-reinforced composite crowns depending upon luting cements. J Korean Acad Prosthodont 2000;38:618-630.

29. Göhring TN, Gallo L, Lüthy H. Effect of water storage, thermocycling, the incorporation and site of placement of glass-fibers on the flexural strength of veneering composite. Dent Mater 2005;21:761-772. doi: 10.1016/ j.dental.2005.01.013.

30. McCabe JF, Rusby S. Water absorption, dimensional change and radial pressure in resin matrix dental restorative materials. Biomaterials 2004;25:4001-4007. doi: 10.1016/ j.biomaterials.2003.10.088.

31. Hirasawa T, Hirano S, Hirabayashi S, Harashima I, Aizawa M. Initial dimensional change of composites in dry and wet conditions. J Dent Res 1983;62:28-31. doi: 10.1177/00220345830620010701.

32. Musanje L, Darvell BW. Aspects of water sorption from the air, water and artificial saliva in resin composite restorative materials. Dent Mater 2003;19:414-422. doi: 10.1016/ s0109-5641(02)00085-4.

33. Segura A, Donly KJ. In vitro posterior composite polymerization recovery following hygroscopic expansion. J Oral Rehabil 1993;20:495-499. doi: 10.1111/j.1365-2842.1993. tb01636.x. 